\title{
Remarks about the taxonomy of some Palaearctic tiger beetles (Coleoptera: Cicindelidae)
}

\section{Замечания по таксономии некоторых видов жкуков скакунов Палеарктики (Coleoptera: Cicindelidae)}

\author{
Andrey V. Matalin \\ A.B. Маталин
}

\begin{abstract}
Moscow State Pedagogical University, Department of Zoology \& Ecology, Kibalchicha str. 6, build. 5, Moscow 129164, Russia. E-mail: a matalin@tochka.ru

Pirogov National Research Medical University, Department of Biology, Ostrovitianova str. 1, Moscow 117997, Russia.

Московский педагогический государственный университет, кафедра зоологии и экологии, ул. Кибальчича, д. 6, корп. 5, 129164 Москва, Россия.

Российский национальный исследовательский медицинский университет им. Н.И. Пирогова, кафедра биологии, ул. Островитянова, д. 1, Москва 117997, Россия.
\end{abstract}

KEY WORDS: Coleoptera, Cicindelidae, tiger beetles, new synonyms, available name, unavailable name, unavailable nomenclature act, valid name, invalid name, new rank, new records.

КЛЮЧЕВЫЕ СЛОВА: Coleoptera, Cicindelidae, жуки скакуны, новые синонимы, пригодное название, непригодное название, непригодный номенклатурный акт, валидное название, невалидное название, новый ранг, новые находки.

ABSTRACT. The taxonomy status of some Palaearctic tiger beetles is discussed. The trinomen Cylindera (s. str.) germanica michaelensis Werner, 1992 is an available name, whereas the trinomen Cicindela silvatica rubescens Jeanne, 1976 is an unavailable name. The synonymy established by Jeanne [1988: 7]: Cicindela silvatica reiseri Mandl, 1970 and Cicindela silvatica rubescens Jeanne, 1976 is an unavailable nomenclature act. Three new synonyms: Cicindela (s. str.) hybrida kozhantshikovi Lutshnik, 1924 = Cicindela (s. str.) kozhantshikovi vaschenkoi Danilevsky, 2001, syn.n., Cicindela (s. str.) restricta restricta Fischer von Waldheim, $1828=$ Cicindela $($ s. str.) restricta tuvensis Danilevsky, 2001, syn.n. and Cylindera (s. str.) germanica bleusei Beuthin, $1904=$ Cylindera (s. str.) germanica michaelensis Werner, 1992, syn.n. are established. In addition Neocollyris (Leptocollyris) minuta Naviaux, 1995, new rank and Therates vitalisi W. Horn, 1913, new rank are now considered as separate species. Both of them are recorded for the first time in the Lampang province of Thailand, while N. minuta is recorded for the first time from Vietnam.

РЕЗЮМЕ. Обсуждается таксономический статус некоторых Палеарктических видов жуков скакунов. Показано, что Cylindera (s.str.) germanica michaelensis Werner, 1992 является пригодным названием, тогда как название Cicindela silvatica rubescens Jeanne, 1976 - непригодно, из-за чего установленная ранее синонимия [Jeanne, 1988] Cicindela silvatica reiseri Mandl, 1970 = Cicindela silvatica rubes- cens Jeanne, 1976 является непригодным номенклатурным актом. Устанавливается следующая синонимия: Cicindela (s. str.) hybrida kozhantshikovi Lutshnik, 1924 = Cicindela (s. str.) kozhantshikovi vaschenkoi Danilevsky, 2001, syn.n.; Cicindela (s. str.) restricta restricta Fischer von Waldheim, $1828=$ Cicindela (s. str.) restricta tuvensis Danilevsky, 2001, syn.n.; Cylindera (s. str.) germanica bleusei Beuthin, $1904=$ Cylindera (s. str.) germanica michaelensis Werner, 1992, syn.n. Кроме того, Neocollyris (Leptocollyris) minuta Naviaux, 1995, new rank и Therates vitalisi $\mathrm{W}$. Horn, 1913, new rank рассматриваются в качестве самостоятельных видов. Оба вида впервые отмечены для провинции Лампанг (Тайланд), а N. minuta впервые указан для фауны Вьетнама.

With the publication of the first volume of the Catalogue of Palaearctic Coleoptera [Löbl \& Smetana, 2003] several taxonomic problems concerning the availability and authorship of some names remained unresolved, particularly in the subfamily Cicindelinae. In the present paper we resolve several of these nomenclature questions and establish three new synonyms, specify the priority of two authors, and change the rank of two taxa.

Studied specimens are kept in the following museums and private collections:

ZISP - Zoological Institute of Russian Academy of Science (St.-Petersburg, Russia);

MPU - Moscow State Pedagogical University (Moscow, Russia); 
SZM - Siberian Zoological Museum (Novosibirsk, Russia);

cAK — collection of Alexander Koval (St.-Petersburg, Russia);

cAN — collection of Alexander Napolov (Riga, RigaZoo, Latvia);

cDF - collection of Dmitry Fedorenko (Moscow, Russia);

cDT - collection of Dmitry Telnov (Riga, Latvia);

cEK - collection of Eugeny Komarov (Volgograd, Russia);

cIB — collection Igor Belousov (St.-Petersburg, Russia);

cIS - collection of Igor Solodovnikov (Vitebsk, Belarus);

cMD - collection of Mikhail Danilevsky (Moscow, Russia);

cMS - collection of Maxim Smirnov (Ivanovo, Rusia); cPU - collection of Pavel Udovichenko (Moscow, Russia);

cSM - collection of Sergei Murzin (Moscow, Russia).

\section{Species accounts}

Cicindela (s. str.) hybrida kozhantshikovi Lutshnik, 1924 Figs 1-4, 7-8, 13-14.

Cicindela sahlbergi kozhantshikovi Lutshnik, 1924: 25 (type locality - Minusinsk)

Cicindela kozhantshikovi vaschenkoi Danilevsky, 2001: 145, syn. nov. (type locality — Khadyn Lake, Tuva Republic)

TYPE MATERIAL. Lectotype of Cicindela sahlbergi kozhantshikovi Lutshnik, 1924 [designated by Matalin (1999: 37)], О' "Kaptyrevo, Minusinskydistr., V-VI.1916, Starodubtsev", "Lectotypus, Cicindela sahlbergi kozhantshikovi Lutshnik, 1924, design. Matalin A.V., 1999" (ZISP); Paralectotypes of Cicindela sahlbergi kozhantshikovi Lutshnik, 1924 [designated by Matalin (1999: 37)]: O' (with partly damaged abdomen and without aedeagus) - "Kaptyrevo, Minusinsk distr., 2-24.VII.1916, Starodubtsev", "Paralectotypus, Cicindela sahlbergi kozhantshikovi Lutshnik, 1924, design. Matalin A.V., 1999"; 으 - "Minusinsk, Enyseiskaya prov., V.1917, Kozhantshikov", "Syntypus, Cic. hybrida kozhantshikovi Lutsh., Shilenkov det. 95", "Paralectotypus, Cicindela sahlbergi kozhantshikovi Lutshnik, 1924, design. Matalin A.V., 1999"; 우 — "Tibercul Lake, Minusinsky distr., VI.1920, Kozhantshikov", "Syntypus, Cic. hybrida kozhantshikovi Lutsh., Shilenkov det. 95", "Paralectotypus, Cicindela sahlbergi kozhantshikovi Lutshnik, 1924, design. Matalin A.V., 1999” (all ZISP).

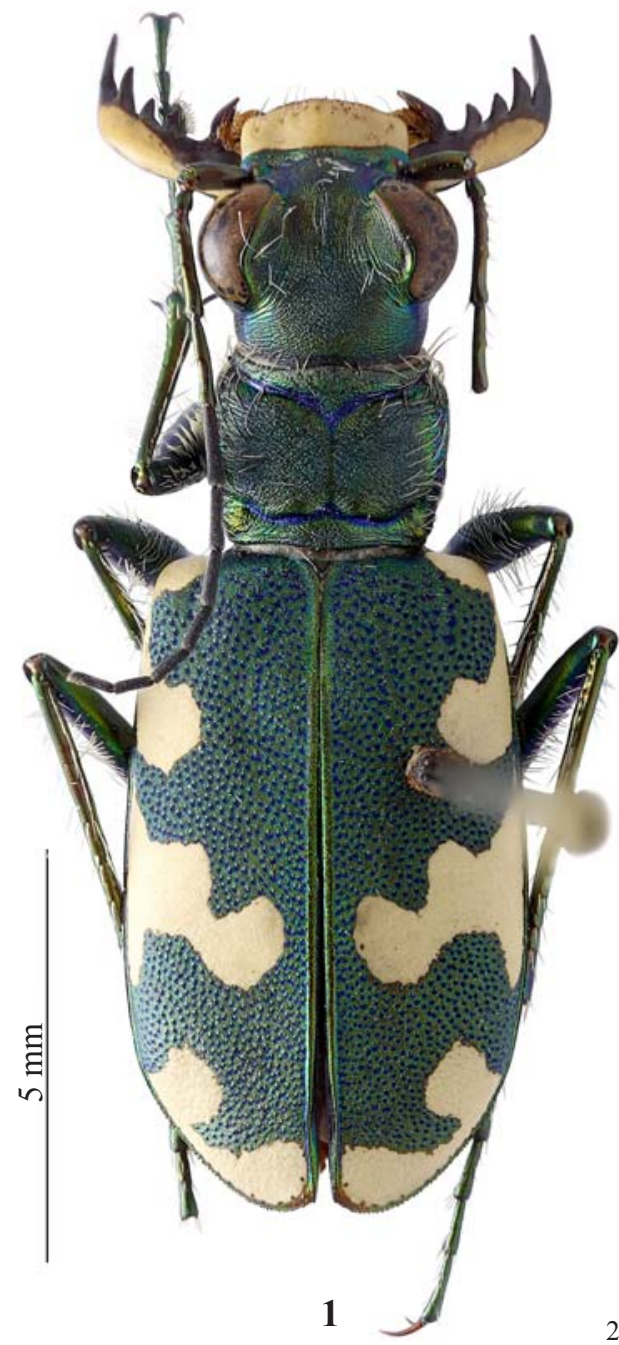

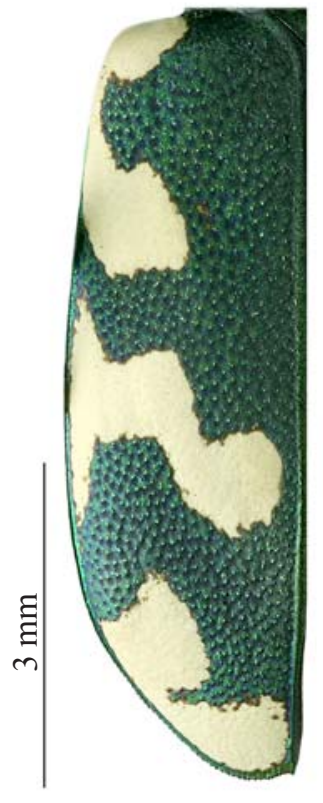

2

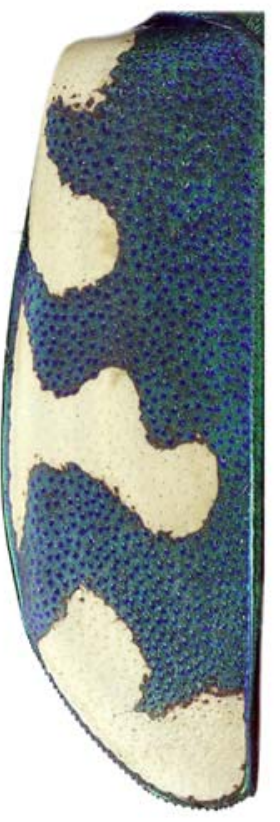

3

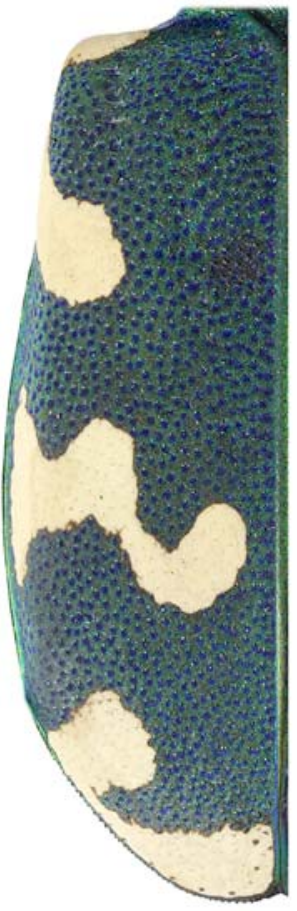

4

Figs 1-4. Types specimens of C. saglbergi kozhantshikovi: 1 - lectotype, habitus; 2-4 - paralectotypes, left elytron; 1-2 — males; 3-4 - females.

Рис. 1-4. Типовые экземпляры C. saglbergi kozhantshikovi: 1-лектотип, габитус; 2-4 - паралектотипы, левое надкрылье; 1-2 - самцы; 3-4 - самки. 
Paratypes of Cicindela kozhantshikovi vaschenkoi Danilevsky, 2001, $2 \sigma^{\top} \sigma^{7}$ — "Russia, Tuva Republic, Khadyn Lake environs, 23-25.5.1998, A. Vaschenko leg.", "Paratype, Cicindela kozhantshikovi vaschenkoi det. Danilevsky, 2001" (cMD).

ADDITIONAL MATERIAL. Russia. Chelyabinsk Region: $10^{\Upsilon 1} 1$ - Y Yantyshevo vill., Sakmara River valley, 21.VI.1996, leg. Yu. Mikhailov (MPU); Tyumen Region: $10^{7}-$ Tyumen, Gilevskaya holt, former riverbed, 5.VI.1993, leg. D. Lomakin (MPU); Altai Republic: $2 \sigma^{7} \sigma^{7}$ - Chemal environs, Katun River bank, sandy beach, 25.VI.1995, leg. A. Gorodinsky (MPU); $40^{7} \sigma^{7} 19$ Chemal environs, near Kuyus vill., Katun River bank, 18.VI.1985, leg. V.N. Prasolov (cIB); $20^{7} \sigma^{7}-$ Chemal pass, h $1500 \mathrm{~m}$, 1.VII.1981, leg. V.N. Prasolov (cIB); $2 \sigma^{7} \sigma^{\top}-$ Uznezya vill., 12.VIII.1909, leg. Gorchakovsky (ZISP); $4 \sigma^{\top} \sigma^{\top} 2$ 우 — Seminsky distr., right bank of Katun River, near Ust-Sema vill., h 600 m, sandy beach, 13.VI.1996, leg. A. Matalin \& A. Brinev (MPU) $3 \sigma^{7} \sigma^{7}$ - Shebalino, Katun River bank, 13-20.VI.1991, leg. Goshko (MPU); $3 \sigma^{7} \sigma^{\top} 19$ - Ulagansky distr., Aktash vill., 1-5.V.1987, leg. A. Gorodinsky (MPU); $1 \sigma^{7}$ — Teletskoye Lake, near Artybash vill. 20.VII.1992, leg. V. Patrikeev (MPU); $2 \sigma^{7} \sigma^{\top 1} 19$ - Teletskoye Lake, Kyrsay, 4.VII.1909, leg. Emelyanov (ZISP); 60 - Teletskoye Lake, Chiri, 30.VI.1909, leg. Emelyanov (ZISP); $10^{\gamma} 19-$ Chulyshman River valley, Katuyaryk vill., 21.VI.1994, leg. D. Lomakin (MPU); Khakassia: $8 \sigma^{\top} \sigma^{\top} 300$ - Sorokaozerki, Aidakhol Lake lakeside, 4.VII.1997, leg. V. Patrikeev (MPU); $10^{7}$ - Tashtypsky distr., Bolshoi On River valley, 21-24.VII.1998, leg. A. Brinev (MPU); Novosibirsk Region: $1 \sigma^{7}$ - Novosibirsk, Ob River bank 21.VII.2002, leg. A. Tille (MPU); Kemerovo Region: $290+\mathrm{Kuz}$ netsk Alatau, Amzas River valley, Luzhba vill., 18.VII.1996, leg. Yu. Mikhailov (MPU); Krasnoyarsky Krai: $3 \sigma^{7} \sigma^{\top}-$ Minusinsk, 21.VII.1897, leg. Vagner (ZISP); $10^{\top}$ - Turukhansky distr., Varlamovka River, 12-13.VI.1987, leg. L. Rybalov (MPU); $10^{7}-$ Western Sayan Mnt., Malye Ury, 9-12.VIII.1983, leg. L. Rybaloy (MPU); $10^{7}$ - Evenkiysky distr., Tunguska plateau, Khushma River, 22,VII.1990, leg. Yu. Mikhailov (MPU); Tuva Republic: $2 \sigma^{7} \sigma^{7}$ — Tandinsky distr., Khadyn Lake environs, 20-28.05.1998, leg. S.N. \& A.N. Vaschenko (MPU); $7 \bigcirc^{\top} \sigma^{\top} 3$ 우 — Khadyn Lake lakeside, 16-19.VI.1997, leg. S. Vaschenko \& R. Mishustin (MPU); $6 \sigma^{\top} \sigma^{\top} 290-$ Kyzyl env., bank of Enisey river, 1-6.VI.1997, leg. S. Vaschenko \& R. Mishustin (MPU); $10^{\top} 1$ 우 - Kyzyl distr., vill. Kara-Khaak environs, Bei-Khem Lake lakeside, 20.VI.1997, leg. V. Patrikeev (MPU); $10^{7}$ - Tandinsky distr., Tora-Khem environs, left bank of Enisei River, 12.VII.1998, leg. D. Obydov (MPU); $2 \sigma^{7} \sigma^{7}$ - Dus-Khol Lake lakeside, 21-22.VI.1997, leg. S. Vaschenko \& R. Mishustin (MPU); Irkutsk Region: $10^{7}$ - near vill Utulik, Baikal Lake lakeside, 3.VII.2000, leg. V. Nikulin (MPU); Buryatia Republic: $2 \sigma^{\top} \sigma^{7}$ - Chamar-Daban, 2.VI.1915, leg. S. Rodionoff (ZISP); KazAKHSTAN. Eastern Kazakhstan Region: $7 \sigma^{\top} \sigma^{\top} 3+9$ Leninogorsky distr., near Karaguzhikha vill., Uba River bank, 20 22.VII.1996, leg. S. Vaschenko (MPU).

COMPARATIVE MATERIAL. Cicindela hybrida hybrida Linnaeus, 1758. Bulgaria. $10^{7}-$ Kresna, 5.05.1981, leg. L. Bieber (cSM); Moldova. $10^{\top} 1$ 우 - Kahul distr., $5 \mathrm{~km}$ W Kahul, left bank of Prut River, sandy beach, 25.V.1990, leg. A. Matalin (MPU); UKRAINE. $5 \sigma^{\top} \sigma^{\top} 390$ - near Kiev, 20.V.1989, leg. O. Nalimova (cSM); $20^{\top} \sigma^{\top} 1+$ - Zakarpattia Oblast, Vynohradiv Raion, Chernaya Gora, Tissa River bank, 2.VIII.1981 (cAK); Belarus. $1 \sigma^{\top}-$ Belovezhskaya Pushcha, 26.IV.1986, leg. O. Aleksandrovich (cEK); $1 \sigma^{\top}$ - Vitebsk environs, pine forest edge, 20.IV.1990 (cIS); LATVIA. $10^{7}$ - Marsalaca, 24.06.1996, leg. F. Savich (cDT); $10^{\top}-$ Cekule, 12.05.1991 (cDT); 107 — Ilgas, 9.05.1996, leg. A. Barševskis (MPU); RuSsIA. Kaliningrad Region: $10^{7}$ — Rybachiy, 19.VI.1958, leg. O.L. Kryzhanovsky (ZISP); Moscow Region: $3 \sigma^{7} \sigma^{7}-$ Istra distr., near Pavlovskaya Sloboda vill., 10.VII.1989, leg. A. Matalin (MPU); $3 \sigma^{7} \sigma^{7}$ — Leninsk distr., Rakitki vill. environs, 1-10.IV.1995, leg. P. Udovichenko (MPU); Tver Region: $10^{7} 19-$ Zapadnodvinsky distr., $50 \mathrm{~km}$ SW Zapadnaya Dvina, Zhizhitsa River bank, 15.VIII.1995, leg. K. Makarov (MPU); Yaroslavl Region: $10^{\top}-40$ km W Rybinsk, Borok vill., 30.IV-3.V.1997, leg. D. Fedorenko (MPU); Orel Region: $10^{7}$ — Livensky distr., Sosna River bank, 7.VII.1986, leg. V. Sibanov (MPU); Smolensk Region: $10^{7}-10$ km upstream Voskhody vill., 10.VII.1977, leg. A. Zamesov (MPU); Ryazan Region: $10^{7}$ - Spasskiy distr., Orekhovo vill, pine forest,
15-31.VII.1982, leg. Goncharov (MPU); Voronezh Region: $10^{7}-$ $25 \mathrm{~km}$ NNO Voronezh, Usmansky Bor, 11.V.1992, leg. M. Tsurikov (MPU); Mordovia Republic: $1 \sigma^{7}$ - Mordovian Nature Reserve, biostation, 19.VI.1987, leg. Matveev (cEK); Krasnodar Krai: $10^{7}$ Sochi environs, VIII.1991, leg. Sorokin (cMS).

Cicindela hybrida magyarica Roeschke, 1891. Hungary. $10^{7}-$ Hungaria, Örkény, 5.5.1984, lgt. V. Zieris (cAK); $10^{7} 19$ - Ungarn, Gerebenez, V.M. Puchon (ZISP); $10^{7}$ - Hungar. m., Gerebenez, Reitter (ZISP).

Cicindela sahlbergii Fischer von Waldheim, 1824. - numerous specimens belonging to three subspecies from different localities [see Matalin, 1999].

REMARKS. Originally Cicindela sahlbergi kozhantshikovi was described on the basis of only six specimens, and the bright green colour was indicated as the main identifying characteristic of this subspecies [Lutshnik, 1924: 25, 27]. Similarly, in the original description of Cicindela kozhantshikovi vaschenkoi, it was characterized by "... very intensive blue colour of majority of specimens both in males and females. Several specimens are blue-green and brown ..." [Danilevsky, 2001: 145, figs 4-7]. Besides the study of the type specimens of C. sahlbergi kozhantshikovi (Figs 1-4) [see also Matalin, 1999], and two paratypes of C. kozhantshikovi vaschenkoi Danilevsky, 2001 two males of C. kozhantshikovi vaschenkoi collected together with the type specimens in the same habitat and by the same collectors, as well as seven males and three females collected in the same locality and habitat, but in 1997 by S. Vaschenko and R. Mishustin were studied (see additional material). The ratio of blue, green and brown exemplars among these specimens was $1: 4: 7$. Moreover green, blue-green or blue specimens of this taxon are known from Khakassia and Krasnoyarsky Krai. Thus colour is not an appropriate feature by which to separate these taxa. The coloration of head, pronotum and elytra as well as area of white elytral pattern are extremely variable characters among species of the hybridagroup. For example, in moderately cold and dry continental conditions the dark-coloured specimens (black, blue and bluish-green) of Cicindela coerulea Pallas, 1773 are more abundant in the local populations, while in moderately warm and humid conditions the light-colored specimens (green and copper) prevail [Matalin \& Zimina, 2002].

According to Danilevsky [2001] the shape of the apical part of the median lobe of the aedeagus is the principal distinction between $C$. hybrida L., 1758, C. sahlbergii F.-W., 1824 and C. kozhantshikovi. This comparison is valid for distinguishing $C$. hybrida and $C$. sahlbergii, but it is not reliable for distinguishing $C$. hybrida and $C$. kozhantshikovi. In contrast to C.sahlbergii (Figs 9-10), the curved apical part of the median lobe of the aedeagus is typical in C. hybrida. This feature is strongly pronouncedin $C$. hybrida magyarica Roeschke, 1891 (Fig. 5), less so in the nominative subspecies (Fig. 6), and feebly marked in C. hybrida kozhantshikovi (Figs 7-8). In addition, for all subspecies of $C$. sahlbergii the large, rounded, but not protruding ventro-apical bladder of the internal sac is characteristic (Figs 15-16) [see also Matalin, 1999: figs 84-99]. In the subspecies of C. hybrida (Figs 11-12), including C. hybrida kozhantshikovi (Figs 13-14), the ventroapical bladder is elongate, protruding apically and curved toward the ventro-lateral left bladder. These patterns indicate that $C$. kozhantshikovi is not a separate species as previously determined by Danilevsky [2001], but it should be considered as C. hybrida in the sense of Horn [1926] and Mandl [1935], not as C. sahlbergii Lutshnik [1924] and Gebert [1995], that was previously discussed [see Matalin, 1999].

Thus, the following synonymy is established - Cicindela (s. str.) hybrida kozhantshikovi Lutshnik, $1924=$ Cicindela (s. 

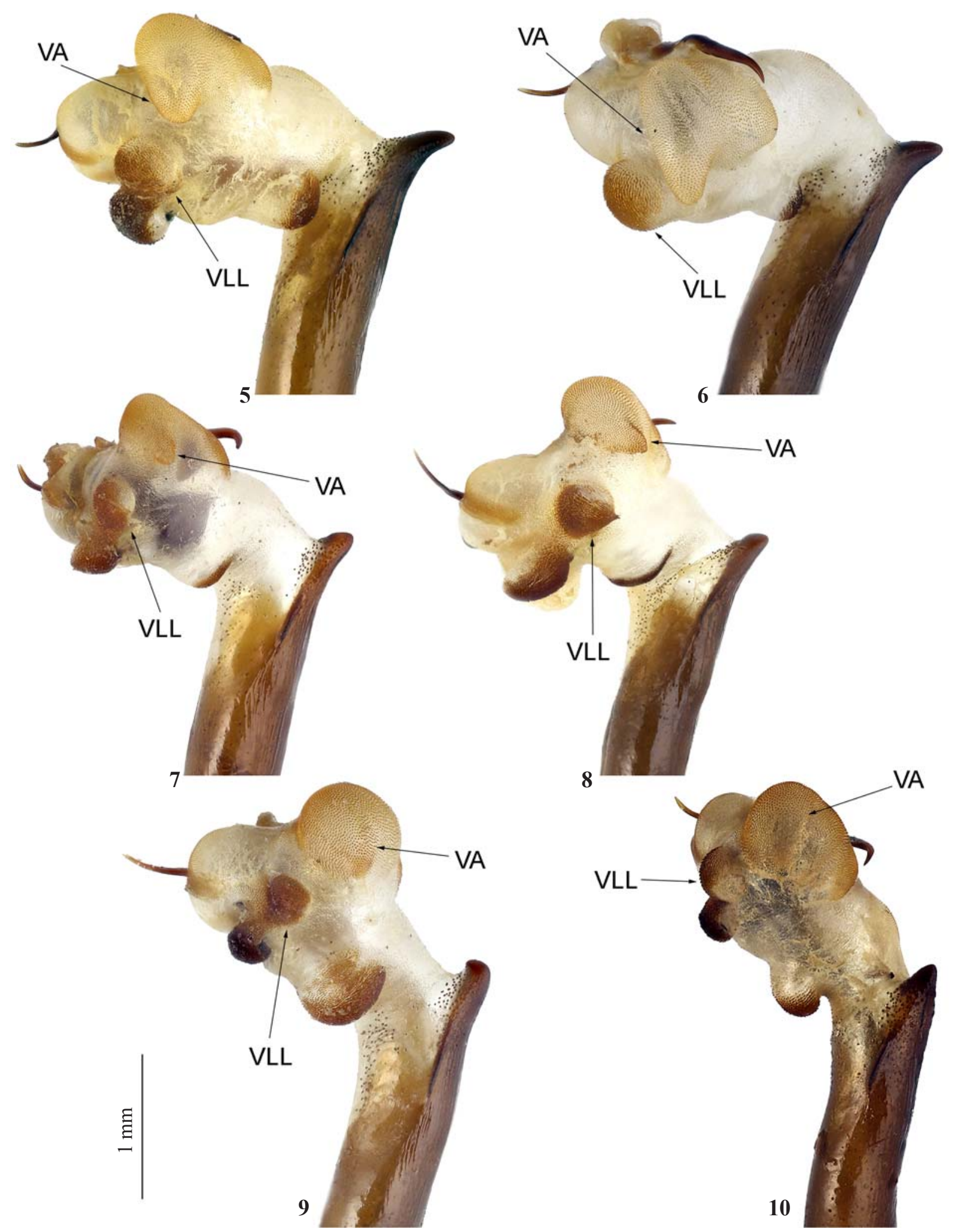

8

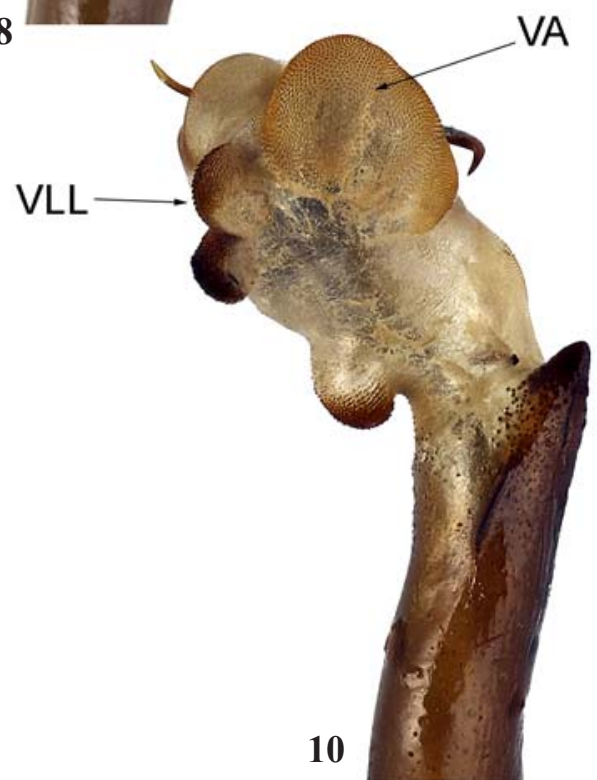

Figs 5-10. Internal sac (left view) of Cicindela spp.: $5-$ C. hybrida magyarica; $6-$ C. h. hybrida; $7-$ C. hybrida kozhantshikovi (lecotype of C. saglbergi kozhantshikovi), partly inflated; $8-$ C. hybrida kozhantshikovi (= C. kozhantshikovi vaschenkoi from Khadyn Lake lakeside); $9-$ C. s. sahlbergii; $10-$ C. sahlbergii khersonensis; VA - ventro-apical bladder; VLL — ventro-lateral left bladder.

Рис. 5-10. Внутренний мешок эдеагуса (слева) Cicindela spp.: 5 - C. hybrida magyarica; $6-$ C. h. hybrida; 7 - C. hybrida kozhantshikovi (лектотип C. saglbergi kozhantshikovi), выдут частично; 8-C. hybrida kozhantshikovi (= C. kozhantshikovi vaschenkoi, экземпляр с берега оз. Хадын); 9 - C. s. sahlbergii; $10-$ C. sahlbergii khersonensis; VA — вентро-апикальный бугор; VLL — левый вентро-латеральный бугор. 

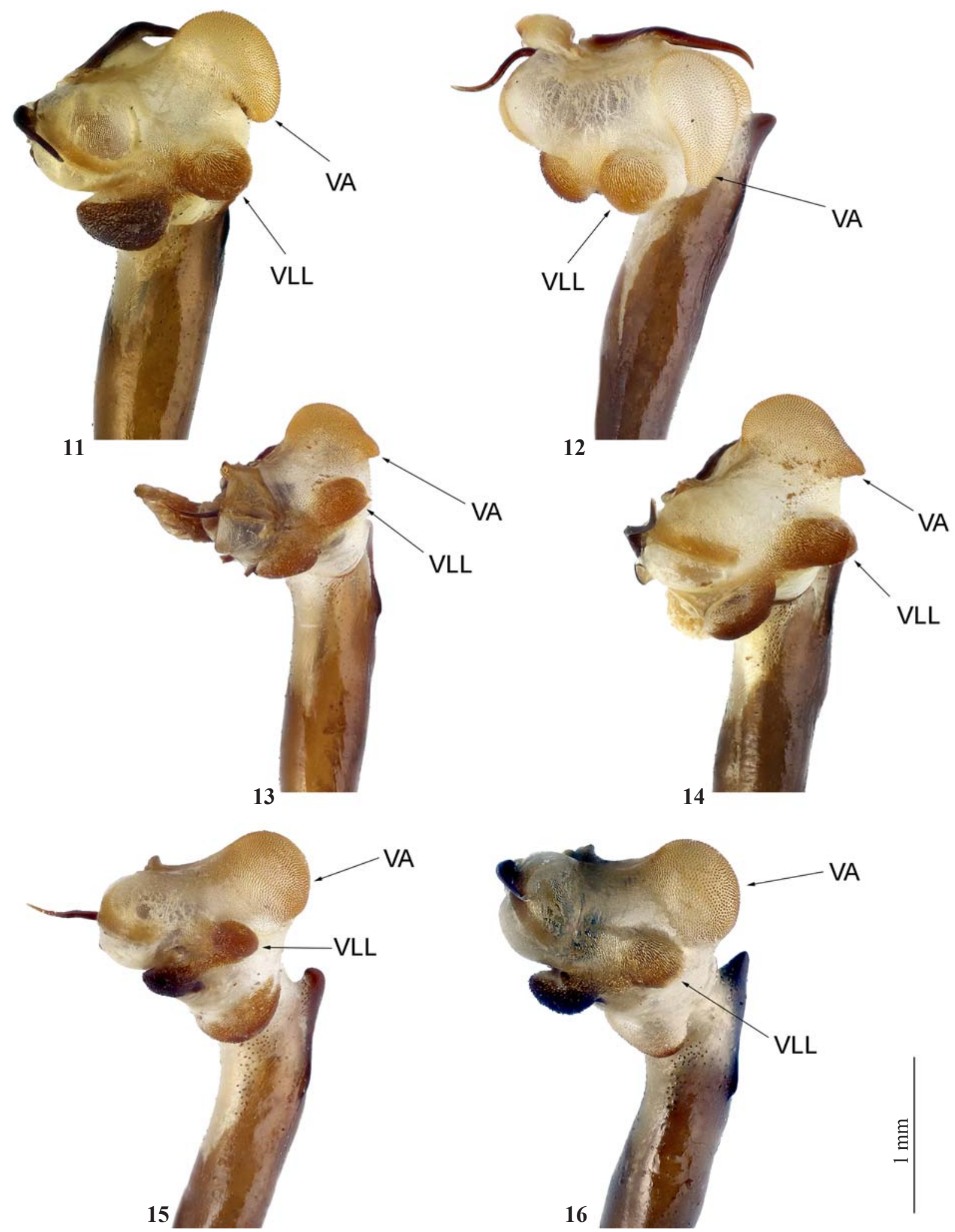

Figs 11-16. Internal sac (ventro-lateral view) of Cicindela spp.:11 - C. hybrida magyarica; $12-$ C. h. hybrida; $13-$ C. hybrida kozhantshikovi (lecotype of C. saglbergi kozhantshikovi), partly inflated; $14-$ C. hybrida kozhantshikovi $(=$ C. kozhantshikovi vaschenkoi from Khadyn Lake lakeside); 15 - C. s. sahlbergii; 16 - C. sahlbergii khersonensis; VA — ventro-apical bladder; VLL — ventro-lateral left bladder.

Рис. 11-16. Внутренний мешок эдеагуса (снизу и сбоку) Cicindela spp.:11 - C. hybrida magyarica; $12-$ C. h. hybrida; $13-C$. hybrida kozhantshikovi (лектотип C. saglbergi kozhantshikovi), выдут частично; 14 - C. hybrida kozhantshikovi $(=$ C. kozhantshikovi vaschenkoi, экземпляр с берега оз. Хадын); 15 - C. s. sahlbergii; 16 - C. sahlbergii khersonensis; VA — вентро-апикальный бугор; VLL - левый вентро-латеральный бугор. 
Cicindela (s. str.) restricta restricta Fischer von Waldheim, 1828

Cicindela hybrida reitteri W. Horn, 1897: 253 (type locality Mongol. bor.)

Cicindela restricta tuvensis Danilevsky, 2001: 145, syn. n. (type locality - Hadek River, Kaa-Khem distr., Tuva Republic)

REMARKS. Cicindela restricta tuvensis was described from Hadek river (Kaa-Khem district, Tuva Republic) and the type series contained 11 males and 15 females [Danilevsky, 2001]. As the main feature of this subspecies "... very intensive blue colour of majority of females ..." was specified [Danilevsky, 2001: 145]. But in subsequent text he stated that some females are green and brown while majority of males are brown. In spite of this the brown male was designated as the holotype [Danilevsky, 2001: 147, fig. 8]. It should be noted that green, greenish-blue, blue and even black colour morphs are observed in different localities throughout the range of $C$. restricta. Such specimens are known from Tuva, Krasnoyarsky Krai, Republic of Yakutia, Irkutsk Region, Republic of Buryatiya, northern Mongolia, northern China and Kamchatka. A similar conclusion was drawn by Danilevsky [2001: 145]. Thus $C$. restricta tuvensis is only a colour morph and not a distinct subspecies.

The following synonymy is thus established - Cicindela (s. str.) restricta restricta Fischer von Waldheim, $1828=$ Cicindela (s. str.) restricta tuvensis Danilevsky, 2001, syn. n.

\section{Cicindela (s. str.) sylvatica reiseri Mandl, 1970}

REMARKS. Jeanne [1967: 4] described the copperbronze specimens of Cicindela silvatica from Picos de Urbión (Iberian System) as an aberration 'rubescens'. According to the Articles 1.3.4, 10.2, 45.5 and 45.6.2 of ICZN [1999] such name is infrasubspecific and thus unavailable. Three years later similarly coloured specimens of Cicindela silvatica from the environs of Reinosa (Cantabrian Mountans) were described by Mandl [1970: 67] as the subspecies ' $r e i$ seri'. Therefore, Mandl's name is available and its priority is unquestionable. In 1976 Jeanne not only indicated two new localities from Cantabrian Mountans (Pico de Tres Mares and Puerto de Pajaros), but also published the trinomen Cicindela silvatica rubescens, and nominally considered the name 'rubescens' as subspecific. However, Jeanne provides neither a description nor a definition, or a bibliographic reference to such a published statement. He also did not propose a new replacement name. Thus according to the Article 13.1 of ICZN [1999] the name Cicindela silvatica rubescens Jeanne, 1976 is also unavailable. For the same reason the synonymy established by Jeanne [1988: 7] is an unavailable nomenclatural act.

Cylindera (s. str.) germanica bleusei Beuthin, 1904

Cicindela germanica var. Bleusei Beuthin, 1904. Societas Entomologica. 19(15): 114 (type locality - Moidrey, Dép.Manche).

Cicindela germanica var. Oberthueri Beuthin, 1904. Societas Entomologica. 19(15): 115 (type locality - Moidrey, Dép.Manche). Cicindela germanica var. semiapicalis Beuthin, 1905. Societas Entomologica. 19(24): 186 (type locality - Moidrey, Dép.Manche).

Cicindela germanica michaelensis Werner, 1992. Die Kafer der Welt. 15: 18 (type locality — Mont Saint-Michel, Manche), syn.n.
REMARKS. In the Catalogue of Palaearctic Coleoptera [Puchkov \& Matalin, 2003] Cylindera (s. str.) germanica michaelensis Vidal y López, 1916 was considered as a valid subspecies. But originally Vidal y López [1916: 518] named this form of Cicindela germanica from Saint-Michel (Mancha) as 's. michaelensis'. According to the Article 32.5.2.4.1 of ICZN [1999] this name is to be written 'sanctaemichaelensis'. Furthermore Cicindela germanica sanctaemichaelensis was unequivocally described as an aberration: "... Igual dibujo, lúnula humeral complete y distinta ... a. S. Michaelensis nov...." [Vidal y López, 1916: 518] and according to the Articles 1.3.4, 10.2, 45.5 and 45.6 of ICZN [1999] this name is infrasubspecific and unavailable.

Later Horn [1926] and all subsequent authors [Barthe, 1931; Cassola \& Brouerius van Nidek, 1984; Werner, 1992; Wiesner, 1992; Lorenz, 1998; Texier, 1998; Putchkov \& Matalin, 2003; Richoux, 2014] quoted this taxon as 'michaelensis' that according to the Articles 33.2.3 of ICZN [1999] is the unjustified emendation. At the same time Cassola and Brouerius van Nidek [1984: 14] were the first to regard Cylindera (s. str.) germanica michaelensis as a subspecies. However, they give neither a description or bibliographic reference to such a published statement, as well as they did not propose a new replacement name. Thus according to the Article 13.1 of ICZN [1999] the name Cylindera germanica michaelensis is not made available by Cassola and Brouerius van Nidek's act. Werner [1992: 18, 44, 70] not only applied this name to a valid subspecies but also accompanied it with a bibliographic reference and photos [1992: P1. 44 figs 381-382]. Thereby according to the Articles 10.2, 23.3.4, 33.2.3, 45.5.1 and 50.3.1 of ICZN [1999] Werner marked the name Cylindera germanica michaelensis is available from Werner [1992].

However, Cicindela germanica var. bleusei Beuthin, 1904, C. germanica var. oberthueri Beuthin, 1904 and C. germanica var. semiapicalis Beuthin, 1905 were described from Moidrey (Departement Manche, France). According to the Articles 10.2 and 45.6.4 of ICZN [1999] these names are available. The names 'oberthueri' and 'semiapicalis' are invalid because they are junior homonyms. The first of these names is preoccupied by Cicindela rufomarginata oberthueri Peringuei, 1888, and the second of these names is preoccupied by Cicindela sylvicola var. semiapicalis Beuthin, 1893. The name 'bleusei' is valid.

Thus the following synonymy is established - Cylindera (s. str.) germanica bleusei Beuthin, $1904=$ Cylindera (s. str.) germanica michaelensis Werner, 1992, syn. nov.

\section{Neocollyris (Leptocollyris) minuta Naviaux, 1995, new rank}

Figs 18, 20, 22.

MATERIAL EXAMINED. Neocollyris (Leptocollyris) variitarsis variitarsis (Chaudoir, 2860). ThaILAND. Lampang Prov.: $1 \sigma^{7}$ - $30 \mathrm{~km}$ SE Lampang City, near Wiang Kosai National Park, h 450 m, 18 $04^{\prime} 01^{\prime \prime} \mathrm{N} 99^{\circ} 39^{\prime} 52^{\prime \prime} \mathrm{E}, 2.06 .2010$, leg. V.K. Zinchenko (SZM); Vietnam. Lào Cai Prov.: $10^{7}$ - mountains W Sa Pa, 28.V.1963, leg. O. Kabakov (ZISP); 1 O $^{\top} 2$ 우 - Sa Pa, h 1250 m, 7-14, VI.1998, leg. A Napolov (cAN); 1 - — Hoang Lien Son Mnt. Range, Hoang Lien Nat. Park., Sa Pa vill. environs, $\mathrm{h} \sim 125-1300 \mathrm{~m}$, $22^{\circ} 20^{\prime} \mathrm{N} 103^{\circ} 50^{\prime} \mathrm{E}, 4 . \mathrm{VI} .1998$, leg. A. Napolov (cAN); Tuyên Quang Prov.: $2+0$ - SE Son-Duong, 200-400 m, 15-20.V.1962, leg. O.

Figs 17-22. Details of males of Neocollyris (Leptocollyris) spp.: 17, 19, $21-N$. variitarsis; 18, 20, 22 - N. minuta; 17-18 - habitus; 1922 - aedeagus, left view; 17-20 — specimens from Thailand (near Wiang Kosai National Park); 21-22 — specimens from Vietnam (21 — Chu Yang Sin National Park; 22 — Nam Cat Tien National Park).

Рис. 17-22. Детали строения самцов Neocollyris (Leptocollyris) spp.: 17, 19, 21 - N. variitarsis; 18, 20, 22 - N. minuta; 17-18 габитус; 19-22 - эдеагус, слева; 17-20 - экз. Из Тайланда (окр. нац. Парка Вианг Кошай); $21-22$ - экз. из Вьетнама (21 - нац. парк Чу Янг Син; 22 - нац. парк Нам Кат Тьен). 
Remarks about the taxonomy of some Palaearctic tiger beetles
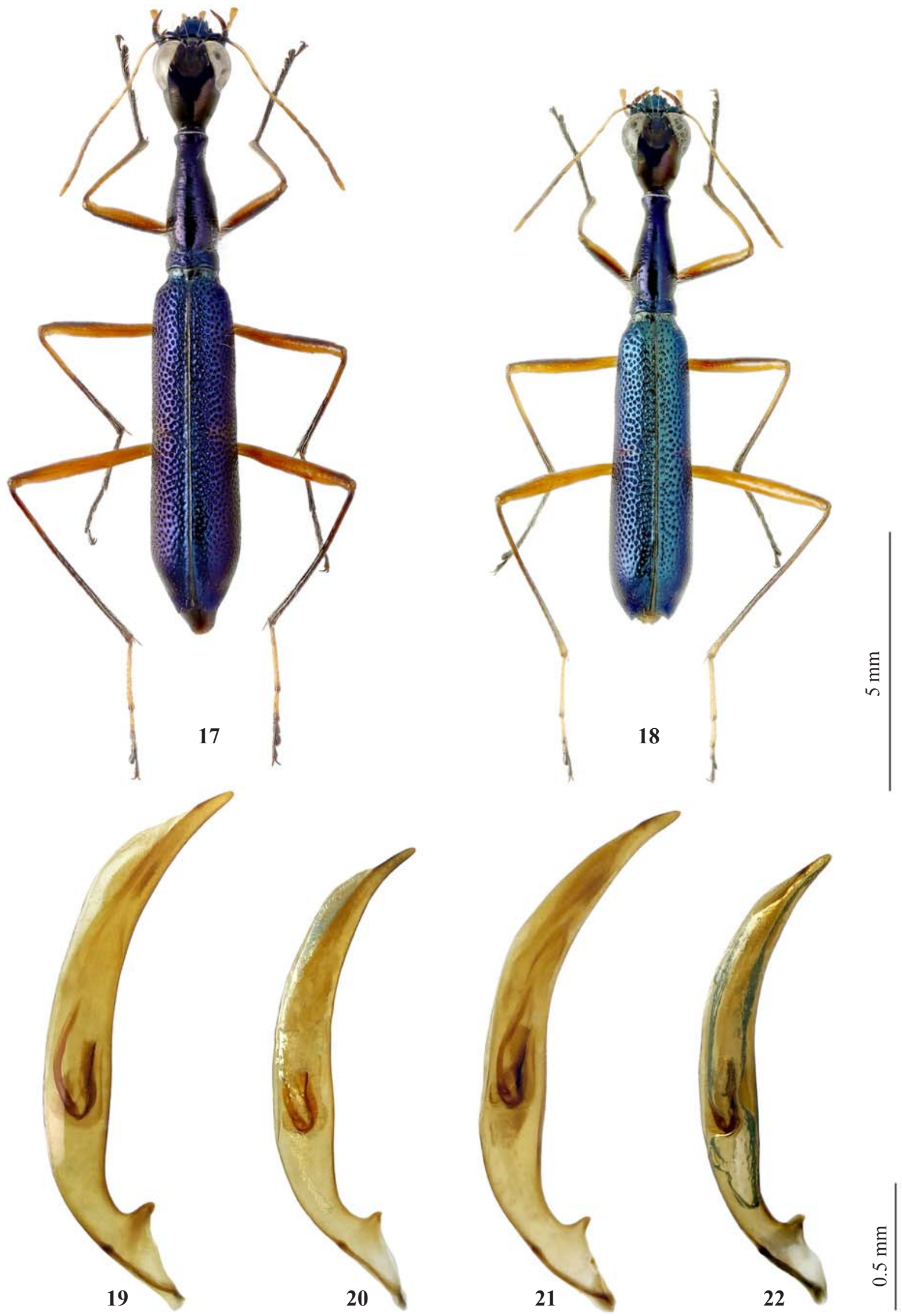
Kabakov (ZISP); $20^{7} \mathrm{O}^{\top} 4$ 4우 - $160 \mathrm{~km}$ NNW Ha Noi, NE env. of Na Hang, h 150-200 m, 29.V-14.VI.1996, leg. A Napolov \& I. Roma (cAN, MPU); Phú Tho Prov.: $10^{7}$ - Tan Son, 16.IV.1962, leg. Izokh (ZISP); Quảng Ninh Prov.: 1 우 $-30 \mathrm{~km}$ N Hong Gai, 14.VI.1962, leg. O. Kabakov (ZISP); Nghệ An Prov.: $10^{\text {T}}-\mathrm{NO}$ Con Cuong, 400 m, 22.IV.1962, leg. O. Kabakov (ZISP); $10^{7}-$ W Muong Sen, 1200 m, 7.X.1962, leg. O. Kabakov (ZISP); Đắk Lăăk Prov.: $50^{7} 0^{\prime 3} 3$ 우 - Chu Yang Sin Nat. Park, on light, 16-30.V.2014, leg. D. Fedorenko (cDF, MPU).

Neocollyris (Leptocollyris) variitarsis minuta Naviaux, 1995. Thailand. Lampang Prov.: $10^{7}-30 \mathrm{~km}$ SE Lampang City, near Wiang Kosai National Park, $\mathrm{h} \sim 450 \mathrm{~m}, 18^{\circ} 04^{\prime} 01^{\prime \prime} \mathrm{N} 99^{\circ} 39^{\prime} 52^{\prime \prime} \mathrm{E}$, 2.06.2010, leg. V.K. Zinchenko (SZM); Vietnam. Đông Nai Prov.: $10^{7}$ - Nam Cat Tien Nat. Park, 8.VI.2004, leg. D. Fedorenko (cDF); $20^{7} 0^{7} 3$ 우우 — same locality, 3-15.VI.2005, leg. D. Fedorenko (cDF, MPU).

REMARKS. Originally Neocollyris minuta was described as a subspecies of Neocollyris variitarsis (Chaudoir, 1860) [Naviaux, 1995]. Until now $N$. variitarsis minuta was known only from the southern provinces of Thailand such as Ranong, Surat Thani, and Trang [Naviaux \& Pinratana, 2004], as well as from Sumatra, and the continental part of Malaysia [Naviaux, 1995]. The range of $N$. variitarsis variitarsis extended from eastern Nepal and eastern India through Myanmar, Thailand, and the southern provinces of China to Laos, and Vietnam [Wiesner, 1992; Naviaux, 1995; Naviaux \& Pinratana, 2004]. Because both forms have been collected together in the same locality and habitat (Thai province Lampang: near Wiang Kosai National Park - see material examined), they are considered here as separate species. Neocollyris minuta can be distinguished by the smaller average size 8.6-10.7 $\mathrm{mm}$ (in N. variitarsis- 10.1-12.7 mm) [Naviaux, 1995: 182-183], greenish-colored elytra (Figs 17-18), as well as by the smaller and less curved aedeagus with shorter median lobe (Figs 19-22). In addition both species are recorded here for the first time in the Lampang province of Thailand, and N. minuta is recorded for the first time for the fauna of Vietnam.

\section{Therates vitalisi W. Horn, 1913, new rank}

Figs 24, 26, 33-37, 39, Map 1.

Therates fruhstorferi vitalisi W. Horn, 1913 (type locality Lao Kay, Tonkin) ien)

Therates ida Mandl, 1954: 159 (type locality — Kuatun, Fuk-

MATERIAL EXAMINED. Therates fruhstorferi fruhstorferi W. Horn, 1902. Vietnam. Hà Giang Prov: 19 - N from Ha Giang, 500 m, 5.VII.1963, leg. O. Kabakov (ZISP); Lào Cai Prov.:1071 19 - Fan Si Pan Mnt., h = 2380 m, 20.V.1994, leg. V. Sinyaev (cPU); Tuyên Quang Prov: $20^{\top} \mathrm{O}^{\top}-160 \mathrm{~km}$ NNW Ha Noi, NE env. of Na Hang, $\mathrm{h}=150-200 \mathrm{~m}, 5-10 . \mathrm{VI} .1996$, leg. A Napolov \& I. Roma (cAN, MPU); Thái Nguên Prov.: 10 1운 50 km NO Thai Nguen, 300 m, 15.V.1963, leg. O. Kabakov (ZISP); $30^{7} 0^{2} 2$ 오 — Tam Dao environs, 900 m, 20.V.1962, 1.VII.1962, 29.VII.1962, 30.VIII.1963, leg. O. Kabakov (ZISP); $10^{7}-$ Tam Dao environs, $800 \mathrm{~m}$, 12.VI.1994, leg. Sugonjaev (ZISP); $10^{\top} 4$ 우 — Tam Dao, 25.V10.VI.1995, leg. Gorochov (ZISP); Hà Nội: $10^{7}-45 \mathrm{~km} \mathrm{~W}$ of Hanoi, Ba Vi Nat. Park, $h=1050-1100 \mathrm{~m}$, leaf-litter, $21^{\circ} 04^{\prime} \mathrm{N}$ 105'21'38”'E, 18.VI.2014, leg. D. Fedorenko (cDF); Phú Tho Prov.: $110^{7} \mathrm{o}^{7}-90 \mathrm{~km} \mathrm{~W}$ of Hanoi, Xuan Son Nat. Park, $\mathrm{h}=400-700 \mathrm{~m}$, $21^{\circ} 07^{\prime} 01^{\prime \prime} \mathrm{N} 104^{\circ} 56^{\prime} 39^{\prime \prime} \mathrm{E}, 6-15 . \mathrm{VI} .2014$, leg. D. Fedorenko" (cDF, MPU); $30^{7} 0^{7}-$ same locality, $h=400-470 \mathrm{~m}, 21^{\circ} 07^{\prime} 52^{\prime \prime} \mathrm{N}$ $104^{\circ} 57^{\prime} 07^{\prime \prime} \mathrm{E}$, 6-15.VI.2014, leg. D. Fedorenko (cDF); $20^{7} 0^{7}-$ same loclit, $\mathrm{h}=300 \mathrm{~m}, 21^{\circ} 07^{\prime} 58^{\prime \prime} \mathrm{N} 104^{\circ} 55^{\prime} 45^{\prime \prime} \mathrm{E}$, river valley, 615.VI.2014, leg. D. Fedorenko (cDF); Hòa Bình Prov.: $30^{7} 0^{7} 1$ 우 Yen Thuy distr., Loc Thin, Cuc Phuong Nat. Park, $20^{\circ} 23^{\prime} \mathrm{N} 105^{\circ} 34^{\prime} \mathrm{E}$, 3-6.V.2002, leg. S. Belokobylsky (ZISP, MPU); Quàng Bình Prov.: $10^{7}-$ NW Dong Hoi, 200 m, 26.II.1963, leg. O. Kabakov (ZISP); $10^{7}$ - Minh Hoa dsitr., Yen Hop environs, 20.IV.199, leg. A. Devyatkin (cDF)

Therates fruhstorferi vitalisi W. Horn, 1913. VIETnAM. Lào Cai Prov.: $10^{T} 2$ of - Hoang Lien Son Mnt. Range, Hoang Lien Nat. Park., Sa Pa vill. environs, $\mathrm{h}=125-1300 \mathrm{~m}, 22^{\circ} 20^{\prime} \mathrm{N} 103^{\circ} 50^{\prime} \mathrm{E}$, 4.VI.1998, leg. A. Napolov (cAN, MPU); $10^{\prime 2} 2$ 우 — near Sa Pa, 1600 m, 11.VIII.1962, 4.VI.1963, leg. O. Kabakov (ZISP); Phú Tho Prov.: $50^{7} 0^{\mathrm{T}} 2+9+90 \mathrm{~km} \mathrm{~W}$ of Hanoi, Xuan Son Nat. Park, $\mathrm{h}=$ 400-700 m, 21 ${ }^{\circ} 07^{\prime} 01^{\prime \prime} \mathrm{N} 104^{\circ} 56^{\prime} 39^{\prime \prime} \mathrm{E}, 6-15 . V I .2014$, leg. D. Fedorenko (cDF, MPU); $20^{7} 0^{7} 1$ 우 - same locality, $\mathrm{h}=400-470 \mathrm{~m}$, $21^{\circ} 07^{\prime} 52^{\prime \prime} \mathrm{N} 104^{\circ} 57^{\prime} 07^{\prime \prime} \mathrm{E}, 6-15 . \mathrm{VI} .2014$, leg. D. Fedorenko (cDF); Hòa Bình Prov.: 19 - Mai Chau distr., Pa Co, Xa Linh, $\mathrm{h}=1120 \mathrm{~m}$, $20^{\circ} 44^{\prime} \mathrm{N} 104^{\circ} 55^{\prime} \mathrm{E}, 22-24 . I V .2002$, leg. S. Belokobylsky (MPU); Nghệ An Prov.: 1 1 - NO Con Cuong, 400 m, 22.IV.1962, leg. O. Kabakov (ZISP).

REMARKS. Therates fruhstorferi was described from the Mauson mountain range, Lang Son, Tonkin (modern Lang Son province of Vietnam) [Horn, 1902]. Ten years later Therates fruhstorferi sauteri was described on the basis of study two specimens (a male and a female) from Taihorin, Formosa (modern Dalin Township, Chiayi County, Taiwan) [Horn, 1912]. The last subspecies - Therates fruhstorferi vitalisi was described from a single female collected at Lao Kay, Tonkin (modern Lao Cai province of Vietnam) [Horn, 1913].

Presently the nominative subspecies is distributed (Map 1) in the Chinese provinces Hubei [Shook \& Wu, 2010], Hunan [Shook \& Wu, 2007, 2010; Gary Shook, personal report], Guangdong [Li \& Chen, 1993; Shook \& Wu, 2007], Guanxi [Shook \& Wu, 2010; Gary Shook, personal report], Guizhou [Tan et el, 1991; Shook \& Wiesner, 2006; Shook \& $\mathrm{Wu}, 2007$ ] and Yunnan [Li \& Chen, 1993; Shook \& Wu, 2006, 2007] as well as in the Vietnamese provonces Ha Giang, Lao Cai, Tuyen Quang, Thai Nguen, Lang Son, Phu Tho (Northeast region), Hoa Binh (south of Northwest region) and Quang Binh (North Central Coast region) [Horn, 1902; Wiesner, 1988; this paper].

Therates fruhstorferi vitalisi is known (Map 1) from the northern Myanmar province of Kachin [Wiesner, 1999]; the Chinese provinces of Xizang [Li \& Chen, 1993; Sawada \& Wiesner, 2006], Yunnan [Li, 2002; Shook \& Wu, 2007] and Fujian [Mandl, 1954], northern — Louag Nam Tha [Sawada \& Wiesner, 1999a, b], Phongsaly and Oudomxay [Sawada \& Wiesner, 2004], Louang Prabang [Wiesner, 1988; Sawada \&Wiesner, 2000], central — Houa Phanh [Sawada \& Wiesner, 2004], Bolikhamsai [Sawada \& Wiesner, 1996c, 2002] and southern - province Savannakhet [Wiesner, 1988] of Laos, as well as from Northeast (Lao Cai and Phu Tho provinces), Northwest (Hoa Binh province) and North Central coastal (Nghe An province) regions of Vietnam [Horn, 1913; Wiesner, 1988; this paper].

Figs 23-39. Details of males of Therates spp.: 23, 25, 27-32,38 - T. fruhstorferi fruhstorferi; 24, 26, 33-37, 39 - T. vitalisi; 23-24 habitus; 25-26 - club of left antenna; 27, 29-33, 35-37 — aedeagus, left view; 28, 34 - aedeagus, dorsal view; 38-39 — apex of median lobe, left view; 23-29, 33-35, 38-39 - Vietnam, Xuan Son National Park; 30 - Vietnam, Na Hang environs; 31 - Vietnam, Tam Dao environs; 32 - Vietnam, Yen Hop environs; 37 - Vietnam, Sa Pa environs; lc - lateral carina.

Figs 23-39. Детали строения самцов Therates spp.: 23, 25, 27-32,38 - T. fruhstorferi fruhstorferi; 24, 26, 33-37, 39 - T. vitalisi; 2324 - габитус; $25-26$ - булава левого усика; 27, 29-33, 35-37 - эдеагус, слева; 28,34 - эдеагус, сверху; 38-39 - ламелла пениса, слева; 23-29, 33-36, 38-39 - Вьетнам, нац. парк Хуан Сон; 30 - Вьетнам, окр. На Ханг; 31 - Вьетнам, окр. Там Дао; 32 - Вьетнам, окр. Йен Хоп; 37 - Вьетнам, окр. Ша Па; 1с - боковой киль. 


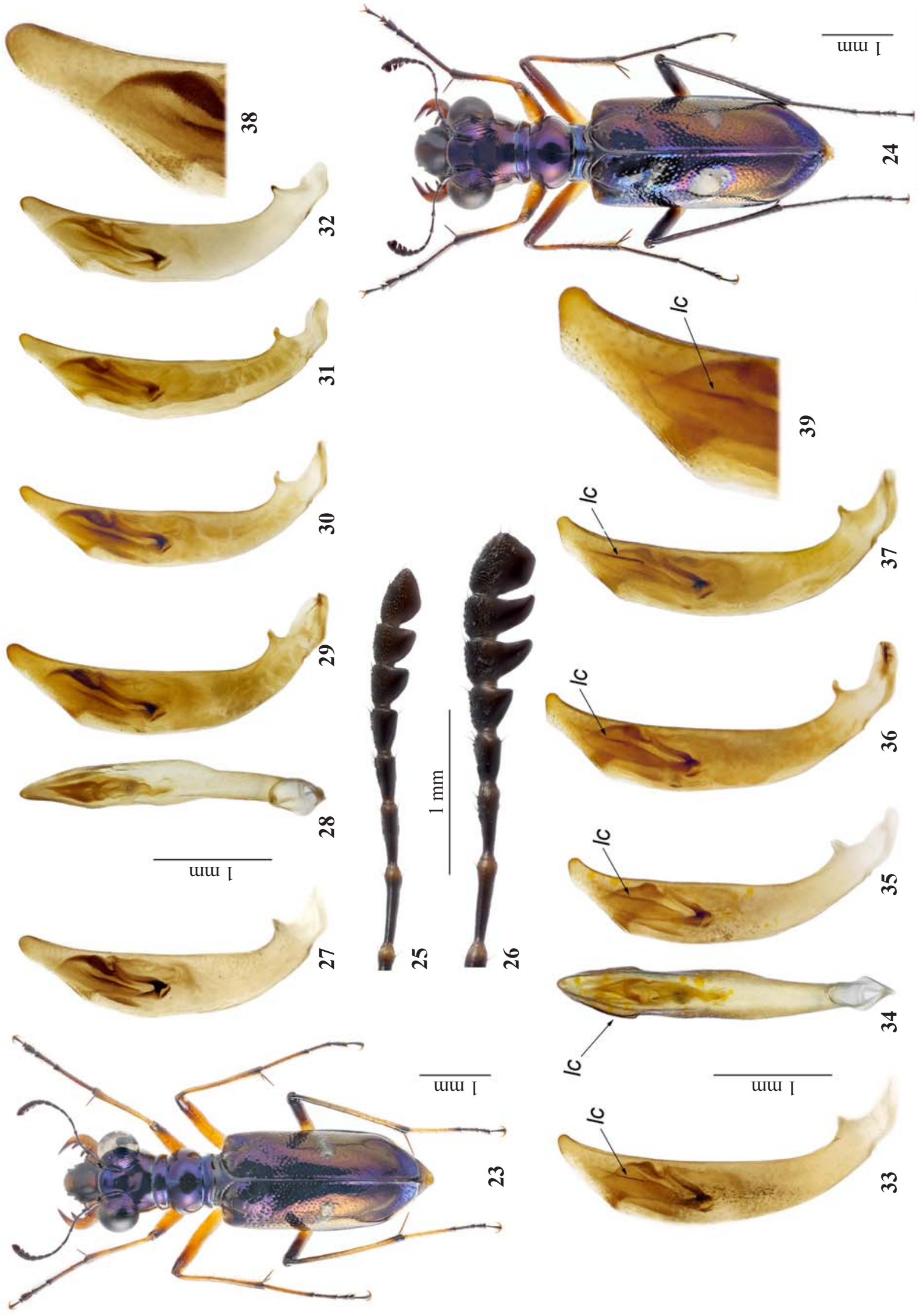




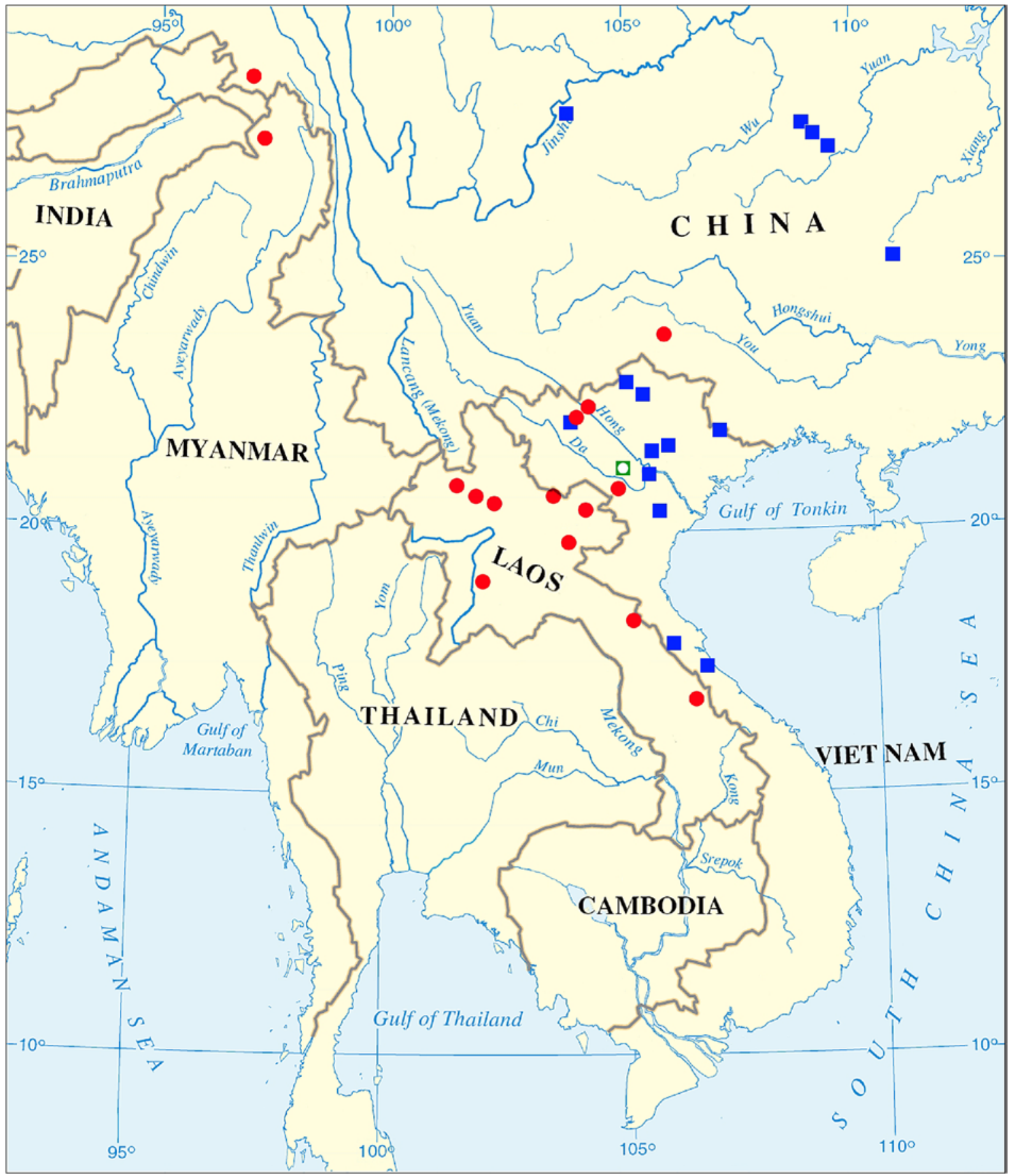

Map 1.Distribution of Therates spp.: blue squares - T. fruhstorferi fruhstorferi; red circles — T. vitalisi; green square with white circle - simpatric zone with syntopic lacality for T. fruhstorferi fruhstorferi and T. vitalisi.

Карта 1. Распространение видов Therates spp.: синие квадраты - T. fruhstorferi fruhstorferi; красные круги — T. vitalisi; зелёный квадрат с белым кругом - точка симпатрии и синтопии T. fruhstorferi fruhstorferi и T. vitalisi.

Finally Therates fruhstorferi sauteri is a Taiwanese endemic.

The subspecies Therates fruhstorferi vitalisi is well distinguished by colouration of the legs (black tarsus, black hind tibia and pale with black apex fore and middle tibia, bilcolored hind femora with pale basal one third and black apical two thirds), lack of pale apical margin on the elytra (Figs 23-24), bulky club-shaped with deeply serrated 9-10 antennomeres (Figs 25-26), the shape of the aedeagus (Figs 27-37), and clear curved apex of it median lobe with distinct lateral carina (Figs $28,34,38-39)$. Due to the fact that both these taxa were collected together in the same locality and habitat (Vietnamese provinces Phú Tho: Xuan Son National Park — see material examined) they are considered here as separate species. 
AKNOWLEGEMENTS. I give many thanks to Dr. Boris Kataev (St-Petersburg, Russia), Dr. Roman Dudko (Novosibirsk, Russia), Dr. Dmitry Fedorenko, Dr. Mikhail Danilevsky, Dr. Sergei Murzin and Mr. Pavel Udovichenko (all Moscow, Russia), Dr. Alexander Koval and Dr. Igor Belousov (both St.-Petersburg, Russia), Mr. Alexander Napolov (Riga, RigaZoo, Latvia), Mr. Dmitry Telnov (Riga, Latvia), Dr. Eugeny Komarov (Volgograd, Russia), Mr. Maxim Smirnov (Ivanovo, Rusia), Dr. Igor Solodovnikov (Vitebsk, Belarus), and Mr. Sergei Vaschenko (Kherson, Ukraine) who kindly loaned materials for this study, to Dr. Jose Serrano (Department of Zoology and Physical Antropology, University of Mursia, Spain) and Dr. Sergei Kurbatov (Moscow, Russia) for assistance in search of some literary sources, as well as to Dr. Gary Shook (Southwest Forestry College, Kunming, Yunnan, China) for information about localities of $T$. fruhstorferi in Chinese provinces Hunan and Guanxi. I am very grateful to Prof. David L. Pearson (School of Life Sciences, Arizona State University, USA http://sols.asu.edu/index.php) and Dr. Yves Bousquet (Agriculture and Agri-Food Canada) for the discussion and revising the English text. This study received financial support of the Ministry of Education and Science of the Russian Federation (Project No 6.632.2014/K).

\section{References}

Barthe E. 1931. Tableaux analytiques des coléoptères de la faune franco-rhénane (France, Hollande, Belgique, Région rhéname, Valais). Famille 1. Cicindelidae // Miscellanea Entomologica. Vol.33. No.9. P.1-41.

Beuthin H. 1893. Über Varietäten paläarktischer Cicindelen // Entomologische Nachrichten (Berlin). T.19. No.4. S.61-62.

Beuthin H. 1904. Zwei neue Varietäten der Cicindela germanica Linné // Societas Entomologica. Vol.19. No.15. P.114-115.

Beuthin H. 1905. Neue Varietäten paläarktischer Cicindelen // Societas Entomologica. Vol.19. No.24. P.186.

Cassola F., Brouerius van Nidek C.M.C. 1984. Checklist of Cicindela (s. auct.) of the Palaearctic Region (Coleoptera: Cicindelidae) // Cicindela. Vol.16. Nos.1-2. P.7-17.

Catalogue of Palaearctic Coleoptera.Vol. 1. Archostemata - Myxophaga - Adephaga. 2003. / I. Löbl, A. Smetana (eds.). Stenstrup: Appolo Books. 819 pp.

Danilevsky M.L. 2001. Two new Cicindela L., 1758 from Tuva Republic (Coleoptera, Cicindelidae) // Lambillionea. Vol.101. No.1. P.144-148.

Fischer [von Waldheim] G. 1825-1828. Entomographia Imperii Rossici. Vol.3. Mosquae. VIII + 314 pp. + XVIII Tab.

Gebert J. 1995. Revision der Cicindela (s. str.) hybrida-Gruppe (sensu Mandl 1935/36) und Bemerkungen zu einigen äuberlich ähnlichen paläarktischen Arten (Coleoptera, Cicindelidae) // Mitteilungen der Münchner Entomologischen Gesellschaft. Bd.86. S.3-32.

Horn W. 1897. Cicindelidarum Novitates // Deutsche Entomologische Zeitschrift. Bd.1897. S.253-256.

Horn W. 1902. Neue Cicindeliden gesammelt von Fruhstorfer in Tonkin 1900 // Deutsche Entomologische Zeitschrift. Jg.1902. S.65-75.

Horn W. 1912. H.Sauter's Formosa-Ausbeute. Cicindelinae // Entomologische Mitteilungen. Bd.1. S.129-139.

Horn W. 1913. Materiaux pour servir à l'étude de la faune entomologique de l'Indochine. Cicindelinae // Annales de la Société Entomologique de Belgique. T.57. P.362-366.

Horn W. 1926. Carabidae: Cicindelinae // Junk W., Schenkling S. (Hrsg.). Coleopterorum Catalogus. Pr.86. Berlin. 345 ss.

International Code of Zoological Nomenclature. Fourth Edition. 1999. London: The International Trust for Zoological Nomenclature. $223 \mathrm{pp}$.

Jeanne C. 1967. Carabiques de la Péninsule Ibérique. ( $4^{e}$ note $) / /$ Actes de la Société Linneenne de Bordeaux. T.104. Sér.A. No.3. P.3-24.
Jeanne C. 1976. Carabiques de la Péninsule Ibérique. (2e supplément) // Bulletin de la Société Linnéenne de Bordeaux. T.6. Nos.7-10. P.27-43.

Jeanne C. 1988. Carabiques nouveaux ou remarquables. ( $8^{\mathrm{e}}$ note) // Bulletin de la Société Linnéenne de Bordeaux. T.16. No.1. P.5-27.

Li H.Z. 2002. List of Chinese insects. Vol. 2. Guangzhou: Zhongshan (Sun Yat-sen) University Press. 612 pp.

Li J., Chen P., 1993. Studies of fauna and Ecogeography of soil animal. China: Northwest Normal University Press. 265 pp.

Löbl I., Smetana A. (eds.). 2003. Catalogue of Palaearctic Coleoptera. Vol.1. Archostemata - Myxophaga - Adephaga. Stenstrup: Appolo Book. 819 pp.

Lorenz W. 1998. Systematic list of extabt ground beetles of the word (Insects Coleoptera "Geadephaga": Trachypachidae and Carabidae incl. Paussinae, Cicindelinae, Rhysodinae). First Edition. Tutzing. Germany. 503 pp.

Lutshnik V. 1924. [Descriptive catalogue of carabid beetles of Minusinsk Territory. I. Introduction. Cicindelina] // Ezhegodnik gosudarstvennogo muzeya imeni Mart'yanova. Vol.2. No.1. P.1-32 [in Russian].

Mand1 K. 1935. Vorarbeiten für eine monographische Neubearbeitung der paläarktischen Cicindelen. Revision der Cicindela hybrida-Gruppe (C. hybrida, coerulea, transbaicalica, altaica, maritima), Zugleich 5, Beitrag zur Kenntnis paläarktischer Cicindelen unter besonderer Berücksichtigung des Materials des Deutschen Entomologischen Instituts in Berlin-Dahlem // Arb. morph. taxon. Ent. Berlin-Dahlem. Bd.2. No.4. P.283-306.

Mandl K. 1954. Zur Kenntnis der Cicindeliden Col.) Süd-Chinas // Bonner Zoologische Beitrage. Bd.5. S.157-161.

Mandl K. 1970. Kleinere Beiträge zur Kenntnis der Familie Cicindelidae // Koleopterologische Rundschau. Bd.48. S.67-74.

Matalin A.V. 1999. The tiger-beetles of the ' hybrida' species-group. II. A taxonomic review of subspecies in Cicindela sahlbergii Fischer von Waldheim, 1824 (Coleoptera, Carabidae, Cicindelinae) // Advanced in Carabidology: Papers dedicated to the memory of professor Oleg L. Kryzhanovskij. Krasnodar: MUISO Publ. P.13-55.

Matalin A.V., Zimina S.V. 2002. Geographis variability of Cicindela coerulea Pall. (Coleoptera, Carabidae) // XII congress of Russian Entomological Society. St.-Petersbourg, August, 1424, 2002. Abstracts. St.-Petersburg. P.230.

Naviaux R. 1995. Les Collyris (Coleoptera, Cicindelidae). Revision des genres et description de nouveaux taxons. Lyon: Société linnéenne de Lyon. 332 pp.

Naviaux R., Pinratana B.A., 2004. The tiger beetles of Thailand (Coleoptera, Cicindelidae). Bangkok: Brothers of St. Gabriel in Thailand: Sunprinting. $177 \mathrm{pp}$.

Peringuey L. 1888. Second contribution to the South African Coleopterous fauna // Transactions of the South African philosiphical Society. Vol.4. P.67-72.

Puchkov A.V., Matalin A.V. 2003. Subfamily Cicindelinae Latreille, 1802 // I. Löbl, A. Smetana (eds.). Catalogue of Palaearctic Coleoptera. Vol.1. Archostemata - Myxophaga - Adephaga. Steenstrup: Appolo Book. P.99-118.

Richoux Ph. 2014. Cylindera (Cylindera) germanica (L., 1758), espèce rare ou discrète? (Coleoptera, Cicindelidae) // L'Entomologiste. T.70. No.5. P.265-268.

Sawada H., Wiesner J. 1999a. Beitrag zur Kenntnis der Cicindelidae (Col.) von Laos (Coleoptera: Cicindelidae) // Entomologische Zeitschrift. Bd.109. H.1. S.27-43.

Sawada H., Wiesner J. 1999b. Records of tiger beetles collected by Mr. Carolus Holzschuh in Laos (Coleoptera: Cicindelidae) // Entomological Revue of Japan. Vol.54. No.1. P.65-77.

Sawada H., Wiesner J. 1999c. Weiterer Beitrag zur Kenntnis der Cicindelidae (Col.) von Laos (Coleoptera: Cicindelidae) // Entomologische Zeitschrift. Bd.109. H.7. S.296-312.

Sawada H., Wiesner J. 2000. New records of tiger beetles collected in Laos (Coleoptera: Cicindelidae) // Entomological Revue of Japan. Vol.55. No.1. P.59-68.

Sawada H., Wiesner J. 2002. Further new records of tiger beetles collected in Laos (Coleoptera: Cicindelidae) // Entomological Revue of Japan. Vol.57. No.1. P.65-99. 
Sawada H., Wiesner J. 2004. Enumeration of the tiger beetles from Laos with description of the three new species (Coleoptera: Cicindelidae) // Entomological Revue of Japan. Vol.59. No.2. P.255-274.

Sawada H., Wiesner J. 2006. New records of tiger beetles from Xizang (China) (Coleoptera: Cicindelidae) // Lambillionea. Vol.106. No.3. T.2. P.462-464.

Shook G., Wiesner J. 2006. A list of the tiger beetles of China (Coleoptera: Cicindelidae) // Fauna of China. Z.-Q. Zhang (ed.). Vol.5. P.5-26.

Shook G., Wu X.-Q. 2006. Range extensions and new species for the tiger beetles fauna of China (Coleoptera: Cicindelidae) // Journa of the Entomological Research Society. Vol.8. Pt.2. P.51-59.

Shook G., Wu X.-Q. 2007. Tiger beetles of Yunnan. Yunnan Publishing Group Corporation - Yunnan Science \& Technology Press. 199 pp

Shook G., Wu X.-Q. 2010. An updated list of the tiger beetles of China.http://asiabeetles.com/files/Second List China TBs2.doc Updated: 15 April 2010.

Tan J.-J., Mo W., Liang C. 1991. [A new species of genus Therates Latreille from Guizhou province, China (Coleoptera: Cicindelidae)] // Sinozooligia. Vol. 5. No.8. P.243-245 [in Chinese with English summary].
Texier E. 1998. La Cicindèle germanique Cylindera germanica (Linné, 1758) en baie du Mont Saint-Michel (Manche): cartographie et polymorphisme // Lettre de l'Atlas entomologique regional (Nantes). No.11. Octobre1998. P.154-173.

Vidal y López M. 1916. I. - Nueva forma de Cicindela (Cylindera) germanica L. // Boletín de la Real Sociedad Española de Historia Natural. T.16. P.517-519.

Werner K. 1992. Cicindelidae regionis Palaearcticae. Cicindelini 2: Cosmodela - Platydela - Lophyra -Habrodera-Chaetodera Neolaphyra - Cephalota - Cassolai - Homodela - Cylindera - Eugrapha - Myriochile - Salpingophora - Hypaeth Abroscelis - Callytron. Die Kafer der Welt, The Beetles of the World, Sciences Nat. France. Vol.15. 94 pp. + P1.31-57.

Wiesner J. 1988. Die Gattung Therates Latr. und ihre Arten. 15. Beitrag zur Kenntnis der Cicindelidae (Coleoptera) // Mitt. Müch. Ent. Ges. Bd.78. S.5-107.

Wiesner J. 1992. Verzeichnis der Sandlaufkäfer der Welt (Checklist of the Tiger Beetles of the World). Keltern: Verlag Erna Bauer. $364 \mathrm{~S}$.

Wiesner J. 1999. Zwei neue Therates Latreille 1817 from Burma (Coleoptera: Cicindelidae)//Entomologische Zeitschrift. Bd.109. H.9. S.369-372. 